\title{
The Review of Hearing Aid Satisfaction and Market Trends in the USA Based on MarkeTrak
}

\author{
Sangik Sim ${ }^{1}$, Jinsook Kim ${ }^{1,2}$ \\ 'Department of Speech Pathology and Audiology, Graduate School, Hallym University, Chuncheon, Korea \\ ${ }^{2}$ Division of Speech Pathology and Audiology, Research Institute of Audiology and Speech Pathology, College of Natural Sciences, \\ Hallym University, Chuncheon, Korea
}

\author{
MarkeTrak을 기반으로 한 미국의 보청기 만족도 및 시장동향 고찰 \\ 심 상 익 ${ }^{1}$ 김 진 숙,2 \\ 한림대학교 일반대학원 언어병리청각학과', 한림대학교 자연과학대학 언어청각학부 · 청각언어연구소 ${ }^{2}$
}

\begin{abstract}
Although there are researches for hearing aid (HA) satisfaction and market trends in USA, MarkeTrak (MT) and Europe, EuroTrak (ET), such could not be found in Korea with increasing demands of HAs. The purpose of this investigation was to establish a systematic base of Korean HA research reviewing MT, which is a good example of HA market trends and satisfaction analysis. Classifying 4 themes, HA features, HA utilities, psycho-social factors, financial factors, MT issues were from 1984 to 2015. The contents included specifically analyzed the main themes, the major considerations for the current HA market, and the factors improving HA satisfaction rates. According to a survey, HA adoption rate has grown by $6.4 \%$ in the USA over 30 years while HA satisfaction rate has increased by $21.4 \%$. The reason for the low adoption rate was reported that the primary motivation to purchase HA was the deterioration of hearing of the individual consumer. The increased satisfaction rate was attributed to the advanced technology that resolved the discomfort factors such as background noise and cosmetic concerning. In addition, the distributing agency of HAs was changed from general dispensers to the audiologists who were professionally educated. MT has put a great impact on investigating HA market in the USA. As Korean HA markets are increasing, it is necessary for the development of KoreaTrak (as the assumed name) such as MT or ET.
\end{abstract}

Key Words: Hearing aid, Hearing aids satisfaction rate, Hearing aid market trends, MarkeTrak.

Received: September 22, 2018 / Revised: January 7, 2019 / Accepted: January 8, 2019

Correspondence: Jinsook Kim, Division of Speech Pathology and Audiology, Research Institute of Audiology and Speech Pathology, College of Natural Sciences, Hallym University, 1 Hallymdaehak-gil, Chuncheon 24252, Korea

Tel: +82-33-248-2213 / Fax: +82-33-256-3240 / E-mail: jskim@hallym.ac.kr

\section{INTRODUCTION}

신체의 어떠한 장애도 사회활동에 많은 어려움을 줄 수 있지 만, 여러 가지 장애 중 청각장애는 초기에 적절한 보청기 착용 과 중재로 다른 장애보다 일상적인 생활에 도움을 많이 얻을 수 있다. 청각장애인의 의사소통 수단으로는 수화나 구화보다는 일 반적인 대화로 들리는 말소리의 의존도가 월등히 높음에도 (Kim et al., 2014) 불구하고 보청기에 대한 부정적인 인식이나 보청기 사용을 통한 재활이라는 개념은 대중적으로 받아들여

(c) This is an Open Access article distributed under the terms of the Creative Commons Attribution Non-Commercial License (https://creativecommons.org/licenses/by-nc/4.0) which permits unrestricted non-commercial use, distribution, and reproduction in any medium, provided the original work is properly cited.
지지 못하고 있다. 특히 등록된 청각장애인 중 $67 \%$ 가 65 세 이상 일 만큼 대부분의 난청인구를 구성하는 노년층에서의(Ministry of Health and Welfare, 2016) 난청에 대한 시각은 더욱 부정적 이다. 왜냐하면 노년기의 난청은 심리·사회적인 고립, 부정적 시각(social stigma), 사회적 외면, 신체적 결함의 표출 등으로 인식되기 때문이다. 또한 최근 연구결과는 노인의 난청은 치매 위험률을 높이고, 의사소통을 단절하고, 정보 획득을 제한함으 로써 사회적 불이익이 심화되고 심지어는 우울증으로도 발전 할 수 있다고 보고하고 있다(Lemke \& Scherpiet, 2013; Lin et al., 2013; Sato et al., 2010). 더욱이 난청으로 유발되는 개인적 인 고통이나 이로 인해 발생되는 사회적 비용을 감안한다면 난 청자에게 적절한 보청기를 공급하고 올바른 청각재활 서비스 
를 제공하는 것은 사회적 사명이라 할 수 있다.

2015년 11월 15일부터 장애등급의 정도와 상관없이 등록한 청각장애인은 보청기를 구매할 때 차상위 계층과 기초생활 수 급자에게 최대 34 만 원에서 131만 원으로 보청기 구매 지원금이 대폭 인상됨에 따라 장애 등록이 가능하였지만 장애인 등록을 하지 않았던 난청인이 적극적으로 청각장애인으로 등록하는 경우가 증가하고 있다. 따라서 2016년 전국에 등록된 장애인 수 중 청각장애는 1 위인 지체장애 다음으로 많은 등록 수를 갖는 출현율 2위인 장애 유형이 되었고, 그 수는 현재 27만 명을 넘어 서고 있다(Ministry of Health and Welfare, 2016). 미국을 비롯 한 외국의 선진 국가들은 점차 늘어나는 청각장애인을 위한 보 청기 수요에 대한 요구를 반영하기 위해 보청기 및 청각재활 서 비스를 효과적으로 제공할 수 있도록 오래 전부터 기본 통계자 료와 보청기의 보급을 확대하기 위한 만족도를 분석하고 소비 자의 인식 및 경향 등에 대한 추적조사를 통해 여러 정책 및 난 청 관련 지원 체계에 관한 기초자료를 구축하고 있다. 그러나 국내에 보청기가 수입되고 보급된 지는 약 40 여 년이 되었고 새 로운 학문으로 청각학이 국내에 소개된 지도 약 20년이 지난 현재, 국내에 난청과 관련된 일반적인 기초 통계조사나 보청기 착용자의 만족도에 대한 조사는 거의 없고 간혹 소수를 대상으 로 한 단편적인 연구들이 간혹 수행되어 왔다.

현재 국내의 난청 및 청각장애와 관련된 전수조사는 2 3년 에 한 번씩 조사되고 있는 국민건강조사 실태보고서가 유일하 다. 2013년의 국민건강조사 실태보고서의 통계에 따르면 양측 성 난청의 출현율은 남성은 $3.3 \%$, 여성은 $3.2 \%$ 로 성별에 따른 차이가 거의 없고, 만 12 세 이상 연령의 양측성 난청 출현율은 60 세 이상에서 남성은 $37.1 \%$ 와 여성은 $28.8 \%$ 로 연령의 증가에 따라 출현율이 증가하고 성별의 차이도 두드러지는 것으로 보 고하고 있다. 보청기와 관련된 조사로는 한국보건연구원에 의 해 2010년에 발간된 난청 환자의 국내 보청기 사용 효과성과 장 애 요인을 전국 12 개 대학병원 내원 환자를 대상으로 설문조사 한 내용을 분석하였다(Ahn, 2010). 연구결과는 보청기의 필요 수요는 점점 증가하고 있으나 보청기에 대한 사회적 인식이나 보청기 착용에 대한 만족도는 수요만큼 변화하지 못하고 있다고 보고하고 있으며, 또한 난청 특성에 맞는 다양한 보청기 처방과 사후관리가 이루어지기 위한 관련 제도의 체계적인 정비가 있어 야 하며 재정적 지원의 확대도 필요하다고 하였다. 이후 Chang et al.(2014)은 MarkeTrak 보고서 8권의 설문조사 내용을 일부 발췌하고 번역하여 해당 병원의 내원 환자에게 조사한 연구에서 우리나라의 보청기 착용자의 전반적인 만족도는 $60.8 \%$ 이며 교 육수준이 높을수록, 남성보다 여성에서, 청취 환경 중 소그룹 대 화에서 더 높은 만족도를 나타낸다고 보고하였다. 더 나아가 저자들은 MarkeTrak 보고서는 청각과 관련된 요인과 사회인구
학적인 견지의 보청기와 관련된 전반적인 요인을 잘 분석한 우 수한 조사라고 평가하였다. 그 이후 Kang et al.(2016)은 MarkeTrak 8권의 설문의 내용이 43항목 134문항으로 문항 수가 많 으므로 설문 응답에 30 분 이상 소요되고, 집중력 저하로 응답에 대한 정확성이 떨어질 수 있는 문제를 제기하여 12 개 항목 53 문 항으로 축약된 설문지로 변형한 설문지를 개발하여 제시하기도 하였으나 이를 통한 연구조사는 아직 보고되지 않았다.

청각학이 처음으로 태동한 미국에서는 청각 관련 산업체의 모임인 청각산업협회(Hearing Industries Association, HIA)에 서 1984년부터 미국 내 모든 난청자 현황, 보청기 착용자 현황, 보청기 착용자의 만족도 등에 대하여 지속적으로 조사한 자료 를 제시하여 오고 있는데 특히 보청기 착용률과 만족도에 대한 연구결과도 함께 제시하고 있다(Kochkin, 1990). HIA로부터 지원을 받은 Knowels사의 Sergei Kochkin에 의해서 처음 발 간되기 시작한 MarkeTrak 보고서는 시장조사기관인 National Family Opinion (NFO) 회원 중 약 20,000명에게 설문조사를 실시한 내용을 기반으로 발간되기 시작하였다. 난청과 관련된 기초자료, 보청기 착용자의 만족도, 보청기 착용률, 보청기 시장 의 동향 등을 포함하며, 1990년부터 2015년까지 9권의 보고서 와 36편의 소주제의 조사결과 보고서를 발간하였다(Abrams \& Kihm, 2015; Kochkin, 1990). 우편 및 방문조사를 통한 설문 조사 방식으로 자료를 수집하였고 조사결과의 일반화를 위해 시장조사 전문 업체에서 미국 전역을 40 개 구역으로 나눈 프리 즘(prism) 구조로 인구분포, 소득수준, 연령분포를 고려한 균 등한 표본집단을 구성하여 조사하였다. 2015년에 발간된 MarkeTrak 보고서 9권에서는 인터넷을 통한 설문조사 방식을 처 음으로 도입하여 조사 기간을 단축하고 결과에 대한 집계와 통 계분석을 신속하고 정확하게 할 수 있는 구조를 마련하였다. 또 한 조사 대상자도 NFO 회원 이외에 일반 대상자도 설문조사 에 참여시켜 설문조사의 범위를 확대하였다. 설문조사 체계에 서는 기존 보고서와는 달리 문항의 체계를 EuroTrak과 유사하 게 보청기 사용 여부에 관계없이 난청에 관련된 설문, 보청기 사 용자에 대한 설문, 보청기 만족도 조사 등으로 변화를 주었다. 이를 통해 EuroTrak의 조사 결과와 직접적인 비교가 가능하도 록 변화를 시도하였다(Abrams \& Kihm, 2015). 보청기 만족도 및 동향에 대한 분석은 보청기 만족도를 높일 수 있는 보청기 의 기능적 특징(hearing aid features), 보청기를 착용함으로써 얻어지는 보청기의 활용(hearing aid utilities), 보청기 착용을 돕거나 방해하는 심리적 요인과 보청기 구매를 꺼려 하는 이유 를 확인할 수 있는 심리·사회적 요인(psycho-social factors), 보청기 구매 및 경제적 가치에 대한 경제적 요인(financial factors) 등의 네 가지 주제를 중심으로 분석하였다. 이 중 1 개의 주제만을 다루기도 하고 2 개나 3 개의 주제를 동시에 다루기도 
한 총 36 편의 보고서를 발간하였다.

유럽의 보청기 관련 제조회사의 연합 단체인 Europe Hearing Instrument Manufacturer Association (EHIMA)이 주축 이 되어 발행하는 EuroTrak은 보청기에 대한 만족도 및 보청 기 시장에 대한 폭넓은 조사로 널리 알려진 또 다른 예이다. EuroTrak은 유럽 내 여러 나라에서 개별로 조사 발표된 내용 을 통합하여 발표하는 형식으로 2009년에 영국, 독일, 프랑스 를 시작으로 처음 발간되기 시작하였다. 또한 EHIMA에 의해 주관되지만 스위스의 시장조사 연구 업체 Anovum에 의뢰하 여 구체적인 조사를 실시하고 결과를 분석한 자료를 보고하고 있다. EuroTrak은 크게 3 개의 카테고리로 구성되는데, 첫째는 일반 보청기 시장조사, 둘째는 보청기 사용인구에 대한 분석, 셋째는 청각장애는 있으나 보청기를 사용하지 않는 인구에 대 한 분석이다. 2009년 이후 현재까지 유럽 내 각국에서 총 22편 의 보고서가 발간되었으며, 아시아 국가 중에서는 대표적인 고 령화 국가로 알려진 일본이 Japan Hearing Instrument Manufacturers Association의 주도로 2012년과 2015년에 두 번 EuroTrak 내에 일본 보청기 시장의 구체적인 조사 내용을 발표 하였다(Anovum, 2013; EHIMA, 2016).

본 연구에서는 전 세계에서 발표되고 있는 보청기 관련 조사 보고서 중 가장 오래되고 체계적인 자료를 제시하고 있는 보고 서인 MarkeTrak 보고서의 전편인 1990년부터 2015년까지 발표 된 총 36편을 고찰하여 미국의 보청기 시장 동향과 만족도 분 석 내용을 보고하고자 하였다. 내용이 비교적 방대하여 본 연 구는 MarkeTrak 보고서 중 우리나라의 보청기 시장과 연관성 이 높은 항목과 보청기 만족도에 영향을 주는 내용을 위주로 고찰하고자 하였다. 예를 들어 미국시장에 한정된 사항인 일반 의사/가족의사(general physician/family doctor)에 의한 추천, 보훈처(Veteran Affairs)의 보청기 보급 및 지원, 우편 판매와 소포 발송과 같은 특이한 유통 경로에 대한 내용은 배제하였 다. 이와 같은 분석 내용을 토대로 국내에서도 MarkeTrak 보 고서와 같은 보청기 만족도 및 시장 현황조사가 필요한지 검토 하고, 국내 현실에 적합한 최신 조사 체계를 수립할 수 있는 기 반을 마련하고 국내 보청기 착용 만족도를 향상시키고 국내 보 청기 시장이 질적으로 개선되고 양적으로 확대될 수 있는 방안 을 검토하고자 한다.

\section{USA HEARING IMPAIRMENT POPULATION AND BASIC STATISTICS OF HEARING AID}

1984 년 약 $16,400,000$ 명 정도로 추정되던 미국의 난청인구 는 10년 후인 1994년에 약 $26,100,000$ 명으로 $59.1 \%$ 의 급진적인 증가를 보이나 그 이후 점차 감소하기 시작해 2008년에 $34,300,000$ 명, 2014년에 33,000,000명으로 약간 감소하는 추세 를 보이고 있다. 30년간의 변화를 정리하면 2014년의 난청인구 는 1984년에 비해 약 두 배 증가하였고 이를 미국의 전체 인구 수와 비교하면 전체 인구의 약 $10 \%$ 정도가 난청을 갖고 있는 것 으로 분석할 수 있다(Abrams \& Kihm, 2015; Kochkin, 1990, 1996, 2009) (Figure 1). 난청인구는 두 배 넘게 꾸준히 증가하였 지만 난청을 극복하는 데 필요한 보조기기인 보청기에 대한 착 용률은 같은 기간에 두 배로 증가하지 못한 것으로 나타났다. 왜냐하면 보청기의 착용률이 1984년에는 23.8\%였으나 2006년 에 24.6\%로 미미한 증가율을 보이다가 2014년에 30.2\%로 증가

Figure 1. The number of total and hear-

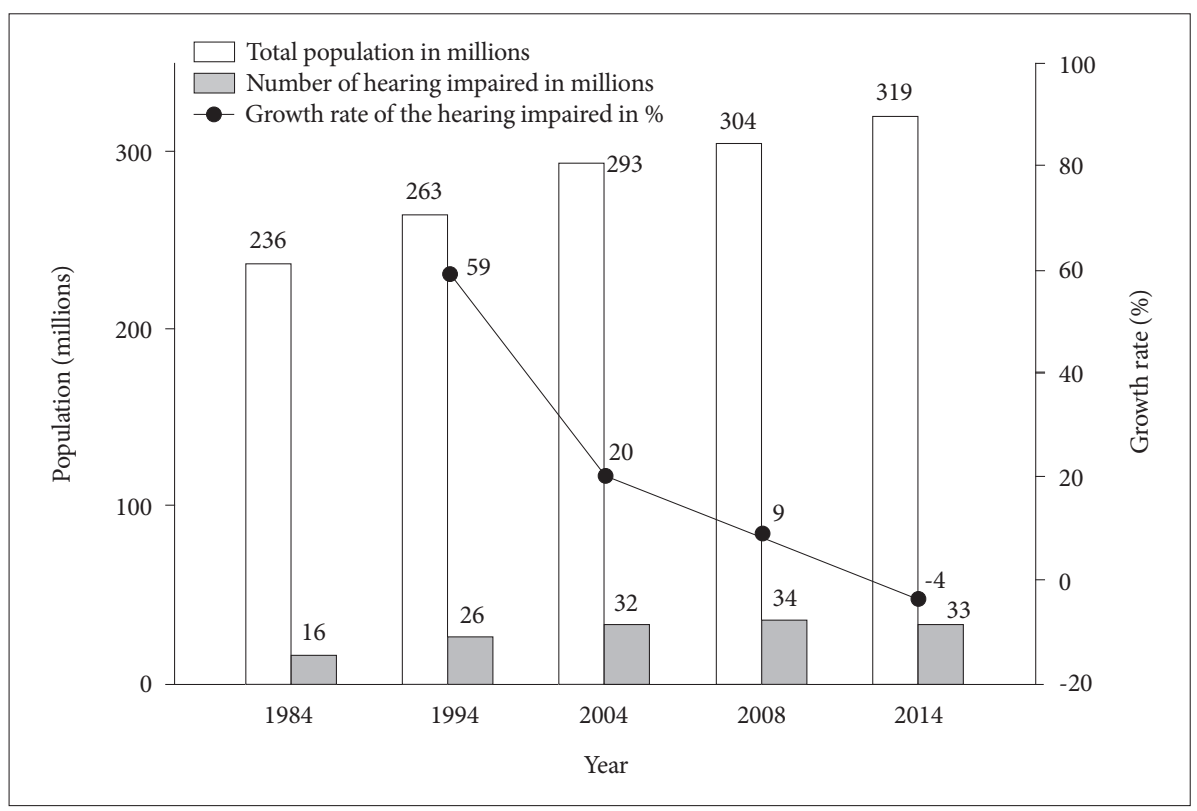
rate of the hearing impaired in USA. 
폭이 인구 증가율을 따라가지 못했기 때문이다(Figure 2).

그 이유를 분석하기 위해 25년간 보청기 착용에 대한 전반적 인 만족도의 조사결과를 비교하였다.

보청기 만족도는 1989년부터 2000년까지는 변화가 거의 없 거나 오히려 조금 떨어지다가 그 이후 점차 증가하기 시작하여 2014년에는 81\%의 높은 만족도를 나타내고 있다. 보청기 착용 비율의 증가 폭은 2000년대 이후 상승하였는데 2000년에 $1 \%$, 2004년에 13\%, 2008년에 6\%, 2014년에 7.0\%로 나타났다(Fig- ure 3).

난청인구의 증가와 보청기에 대한 만족도가 동반 상승되었음 에도 불구하고 보청기 착용률은 상대적으로 증가 폭이 높지 않 은 이유를 확인하기 위해서 MarkeTrak 보고서의 내용을 더 심도 있게 분석하고자 원 저자가 25 주년 기념 인터뷰에서 Gus Mueller에게 밝힌 네 가지 주제, 보청기 특징, 보청기 활용, 심 리·사회적 요인, 경제적 요인 등으로 분류하여 다음과 같이 정 리하였다(Mueller, 2012).
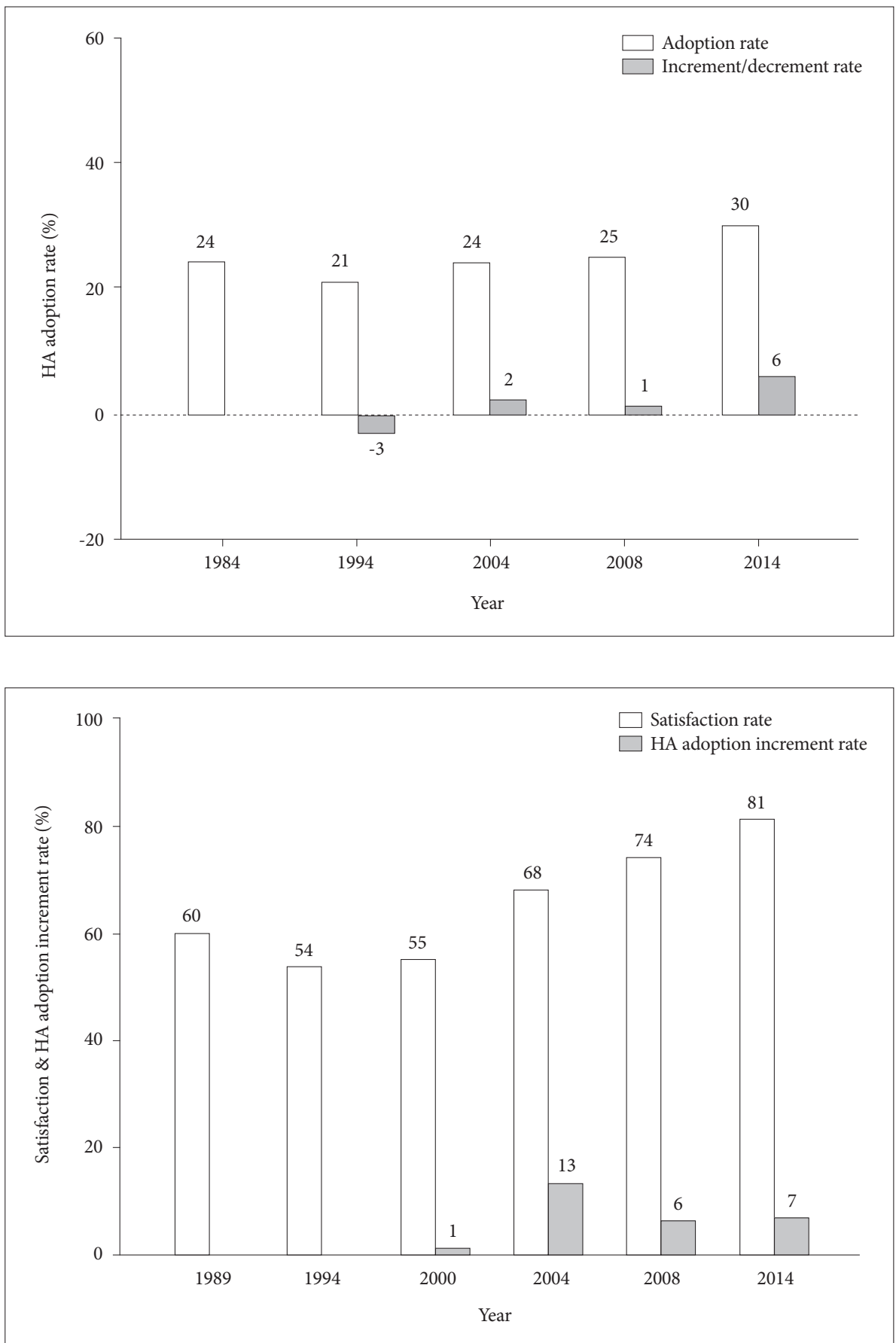

Figure 2. HA adoption rate in the USA. HA: hearing aid. 


\section{보청기 특징(Hearing aid features)}

\section{다양한 청취 환경에서 증폭 기능}

청력손실을 보상하는 단순한 증폭만으로는 보청기에 대한 전반적인 만족도를 기대할 수 없다. 예를 들어, 보청기를 착용 한 이후에 여러 청취 환경에서의 듣기능력 등이 보청기에 대한 전반적인 만족도를 좌우할 수 있기 때문이다(Kochkin, 1990). 다양한 청취 환경에서 듣기능력은 디지털 기술이 보청기에 접 목되어 여러 가지 첨단 알고리즘이 적용되면서 과거보다 많이 개선되었다. MarkeTrak 보고서에 따르면 보청기의 증폭에 대한 만족도가 가장 높은 세 가지 청취 환경은 일대일 대화, 소그룹 대화, TV 시청 환경 순이었고, 만족도가 가장 낮은 세 가지 청 취 환경은 직장 및 작업 환경, 학교 교실, 침실 환경 순이었다. 특히 소음과 반향이 존재하는 청취 환경으로 생각되는 직장 및 작업 환경이나 학교 교실에서 보청기 증폭에 대한 만족도가 낮 은 것으로 나타났다(Kochkin, 1997). 따라서 신호 대 잡음비 가 낮은 소음 상황에서는 조용한 환경이나 일대일 대화와 같이 신호 대 잡음비가 비교적 높은 환경에 비해 여전히 보청기 증 폭의 만족도가 낮은 것으로 보고되었다. 보청기 만족도에 영향 을 미치는 청취 환경을 분석한 MarkeTrak 보고서 3권부터 8권 까지 집중적으로 보고되고 있는 소음 속 상황과 다화자와 대화 를 하여야 하는 청취 환경에 대한 만족도를 살펴보았다. 두 가 지 청취 환경 모두 2002년에 발간된 MarkeTrak 보고서 6권까 지는 만족도가 증가하지 못하다가 2005년 발간된 MarkeTrak 보고서 7권과 2010년 발간된 8권에서 보청기 만족도가 급격히
증가된 것으로 나타났다(Figure 4). 이는 1990년대 후반에 디지 털 기술이 보청기에 탑재되고 보급이 점차 확대되면서 이러한 기술에 대한 기능이 효율적으로 나타난 시기가 2005년 이후인 것으로 해석할 수 있다.

\section{오픈형 보청기(Open type hearing aid)의 출시}

오픈형 보청기는 귀걸이형으로 분류되는 수화기가 외이도에 장착되는 receiver-in-the-canal (RIC)로 출시되었다. 그 이후 귓속형 보청기 판매량이 감소하고 귀걸이형 보청기 판매량은 증가하는 현상이 나타났다. 구체적으로 귓속형 보청기가 전체 보청기 판매량 중 차지하는 비율이 1997년에는 $87 \%$ 였으나, $\mathrm{RIC}$ 보청기의 판매가 활성화된 이후인 2017년에는 불과 $13 \%$ 로 20년 전에 비해 74\%나 감소하였다. RIC 보청기의 비율은 2009 년 24\%였다가 2017년에는 69\%로 증가되어 모든 보청기 형태 중 가장 높은 비율을 차지하는 것으로 나타났다(Hearing review, 2015, 2017) (Figure 5).

RIC 보청기의 판매량이 증가한 이유는 RIC 보청기의 외관이 보청기 착용을 꺼려 하는 요인 중의 하나인 미관상 문제를 해소 하고, 편안한 착용감을 제공하며, 기능적으로는 주변 소음을 효 과적으로 감소시켜 소음상황에서의 듣기 만족도가 개선되는 세 가지로 조사되었다(Kochkin, 2011). 과거에는 귀걸이형 보청기 가 외관상 드러나므로 보청기 착용에 부정적인 영향을 주지만 $\mathrm{RIC}$ 형으로 출시된 오픈형 보청기 판매량의 증가는 외관상의 부 정적인 측면도 어느 정도 해결하고, 외관보다는 기능에 중점을 두는 보청기 착용자들의 성향이 변화한 것으로 해석할 수 있다.
Figure 4. Trend of satisfaction rate in terms of HAs performance and listening situation. HA: hearing aid.

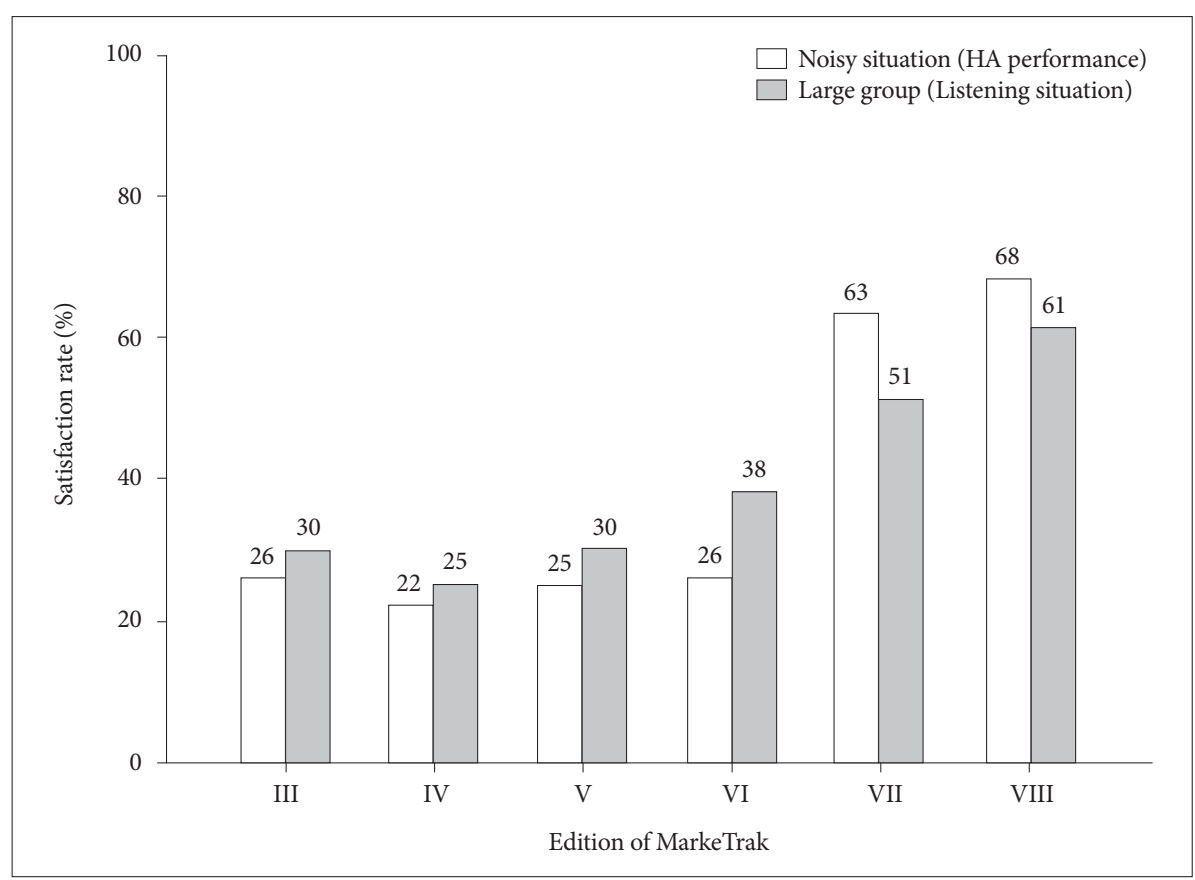


개선 요청 사항(Improvement sought)

MarkeTrak 보고서는 향후 보청기를 개발하고 보급할 때 고 려해야 할 사항들을 파악하기 위해 보청기 착용자들이 차후 개선되었으면 하는 사항에 대한 조사도 시행하였다. 소음 속 말 소리 이해, 더 나은 음질, 적은 음향 되울림, 낮은 가격, 작은 소 리 증폭, 시각적 드러남, 멋스러움, 색상 등 8개의 개선 요구 내 용을 분석할 때 외관과 관련된 개선 요구 사항은 6 8위로 나 타난 반면, 1 4위는 보청기 기능의 개선을 요구하는 것으로 나 타나서 보청기 성능의 개선에 대한 요구가 큰 것으로 나타났다 (Kochkin, 2002a) (Figure 6). 가장 주요하게 개선하였으면 하 는 요소는 소음 속에서 말소리 이해도의 증가인 것으로 나타났

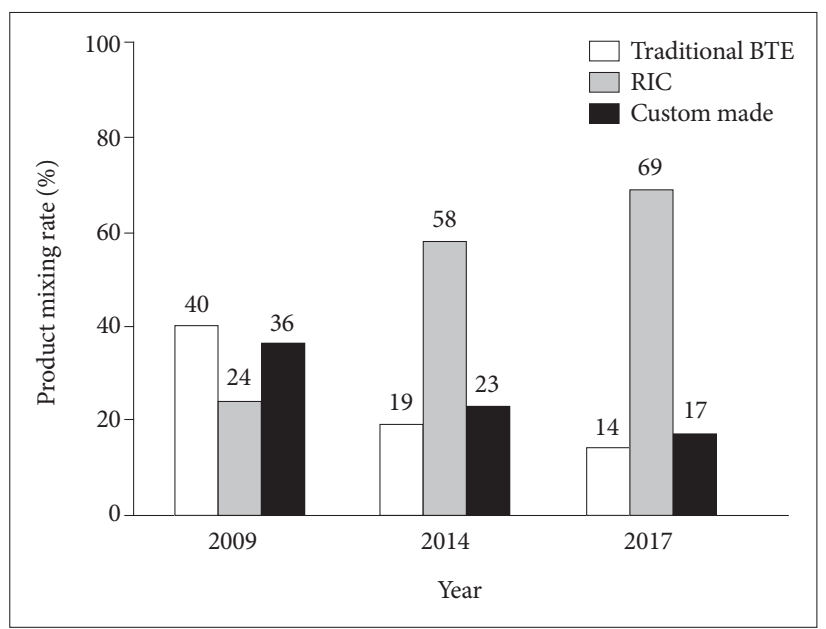

Figure 5. Product mixing of hearing aid type. BTE: behind in the ear, RIC: reciever-in-the-canal.
는데, 이는 과거에 비해 보청기 기능이 개선되어 소음 속에서 듣기능력이 비교적 개선되었음에도 불구하고 다른 요소보다 더 개선 요구가 높은 기능으로 이해할 수 있다. 그러나 난청은 있지 만 보청기를 착용하지 않고 있는 비착용자들은 오히려 보청기 에 대한 부정적 인식이 더 큰 것으로 조사되었는데, 이는 보청 기에 대한 외관 등의 부정적 인식은 보청기를 착용하기 전에는 보청기 착용 결정에 걸림돌이 되지만 보청기를 착용한 이후에 는 보청기의 기능에 더 관심을 갖는 것으로 해석할 수 있다.

\section{보청기의 활용(Hearing aid utilities)}

\section{음량조절기 선호도(Volume control preference)}

모든 청취 환경에서 디지털 보청기의 첨단 알고리즘과 자동 조절 기능이 보청기 착용자에게 $100 \%$ 만족도를 줄 수 없기 때 문에 보청기의 음량조절장치의 필요성은 지속적으로 요구된다. 그러나 귓속형 보청기에 음량조절기를 탑재하여 제작하는 경우 는 점점 줄어들고 있다. 그 이유는 1994년 이전, 즉 디지털 보청 기가 출시되기 이전에는 거의 모든 귓속형 보청기에 음량조절 장 치가 탑재되었으나 디지털 보청기가 본격적으로 보급된 이후 점 차 음량조절장치의 필요성이 감소되었기 때문이다. MarkeTrak 보고서에 따르면 귓속형 보청기의 음량조절장치 탑재 비율은 1994년에는 98\%, 1996년에는 88\%, 1998년에는 81\%, 2001년에 는 $75 \%$ 로 점차 낮아지는 것으로 나타났다. 이를 보청기 착용 경험에 따라 분석하였을 때, 신규 착용자의 경우 음량조절장치 를 탑재하였을 때와 하지 않았을 때에 따른 만족도는 $51 \%$ 와

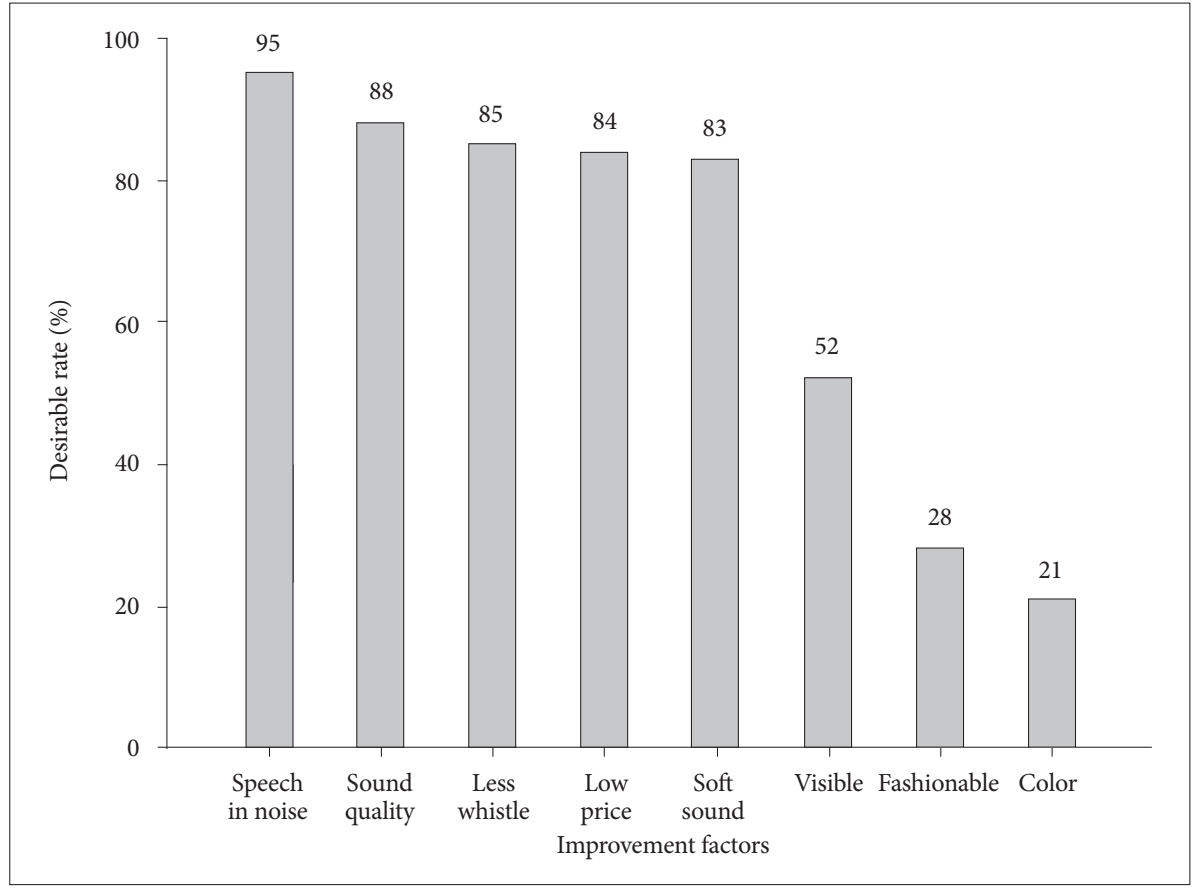

Figure 6. Desirable rate of improvement factors for hearing aids. 
$63 \%$ 로 나타나서 음량조절장치가 있을 때 만족도가 오히려 $12 \%$ 낮은 것으로 나타났다. 반면 기존 착용자의 경우 만족도는 $62 \%$ 와 $63 \%$ 로 음량조절장치의 유무에 따른 만족도는 유사하였 다. 이러한 신규 착용자는 음량조절장치의 탑재로 보청기의 크 기가 커지는 것에 대한 부정적인 인식이 보청기의 만족도를 저 하시키지만 기존 착용자는 음량조절장치의 탑재로 보청기의 크 기가 커지는 것에 대한 영향을 받지 않는 것으로 해석할 수 있 다. 기존 착용자들은 다양한 청취 환경에서 보청기의 음질이나 음량이 만족스럽지 못할 때 음량조절장치로 본인에게 적절한 음질이나 음량 조절을 손쉽게 스스로 조절할 수 있는 장점이 있다고 답변하였다(Kochkin, 2003).

\section{사용시간과 만족도(Usage hour and satisfaction)}

보청기 착용시간은 보청기 착용 만족도와 상관 지어 평가할 수 있는 요인 중 하나이다. 미국 식품의약품안전청(Food and Drug Administration, FDA)의 보청기 사용에 관한 규정인 Code of Federal Regulation의 Title 21에 의하면 보청기는 청 각을 치료하는 도구가 아니라 보조해주는 기기이므로 '하루 4 시간 이상 착용하여 감각기능을 보조해야 한다고 권고하고 있 으며, 간헐적인 보청기의 사용은 보청기를 통해 얻을 수 있는 효과를 최적화할 수 없다고 하여 보청기 착용시간은 적어도 ‘하루 4시간 이상'은 되어야 보청기에 대한 이득을 얻는 것으로 명시하였다(U.S. FDA, 2017). 이를 토대로 MarkeTrak 보고서 는 4시간 이상 보청기를 사용하는 경우를 기존 보청기 착용군 과 신규 보청기 착용군에서 조사하여 각각 $87 \%$ 와 $69 \%$ 인 것을
확인하였다. 그 외 기존 보청기 착용군과 신규 보청기 착용군 에서 2시간 미만 착용하는 경우는 $8.5 \%$ 와 $23.4 \%$ 였고, 보청기 착용을 포기한 경우는 $3.5 \%$ 와 $12.9 \%$ 로 나타났다. 이를 종합하 여 분석하면, 기존 보청기 착용군에서 하루 4 시간 이상 착용자 가 가장 많았고, 2 시간 미만 착용하는 경우와 보청기 착용을 포기한 경우는 신규 보청기 착용군에서 더 많은 것으로 나타 났다. 따라서 신규 착용군이 기존 착용군으로 전환될 수 있도 록 보청기 착용시간을 점차 늘리도록 상담 및 재활이 지속적으 로 필요하며, 신규 보청기 착용자의 초기 보청기 적응 과정의 노력도 중요한 것으로 나타났다. 또한 신규 착용자는 보청기 착 용을 중도에 포기하지 않고 보청기 착용시간을 점차 늘려서 보 청기 사용에 안정적으로 적응하도록 청각전문가의 적절한 적합 과 지속적인 재활 과정이 필요한 것으로 나타났다(Kochkin, 2009, 2010).

\section{심리·사회적 요인(Psycho-social factors)}

\section{부정적 인식 및 외관(Stigma \& cosmetics)}

보청기 착용을 꺼려 하는 여러 이유 중 하나가 보청기를 착용 하였을 때 타인에게 어떻게 보여지는지에 대한 걱정으로 생기 는 외관상의 부정적 인식이다. 이를 구체적으로 '신체적으로 허 약해 보임', 사람들이 조롱함' ‘장애인으로 보임', ‘착용하기 부 끄러움, '정신적으로 허약해 보임' 등의 다섯 가지 요인으로 분 석한 1998년 4권 자료와 2007년 7권 자료를 비교하였을 때, 다 섯 가지의 모든 항목에서 보청기 착용을 꺼려 하는 요인으로

Figure 7. The reason for non-adoption hearing aids in terms of stigma and cosmetics.

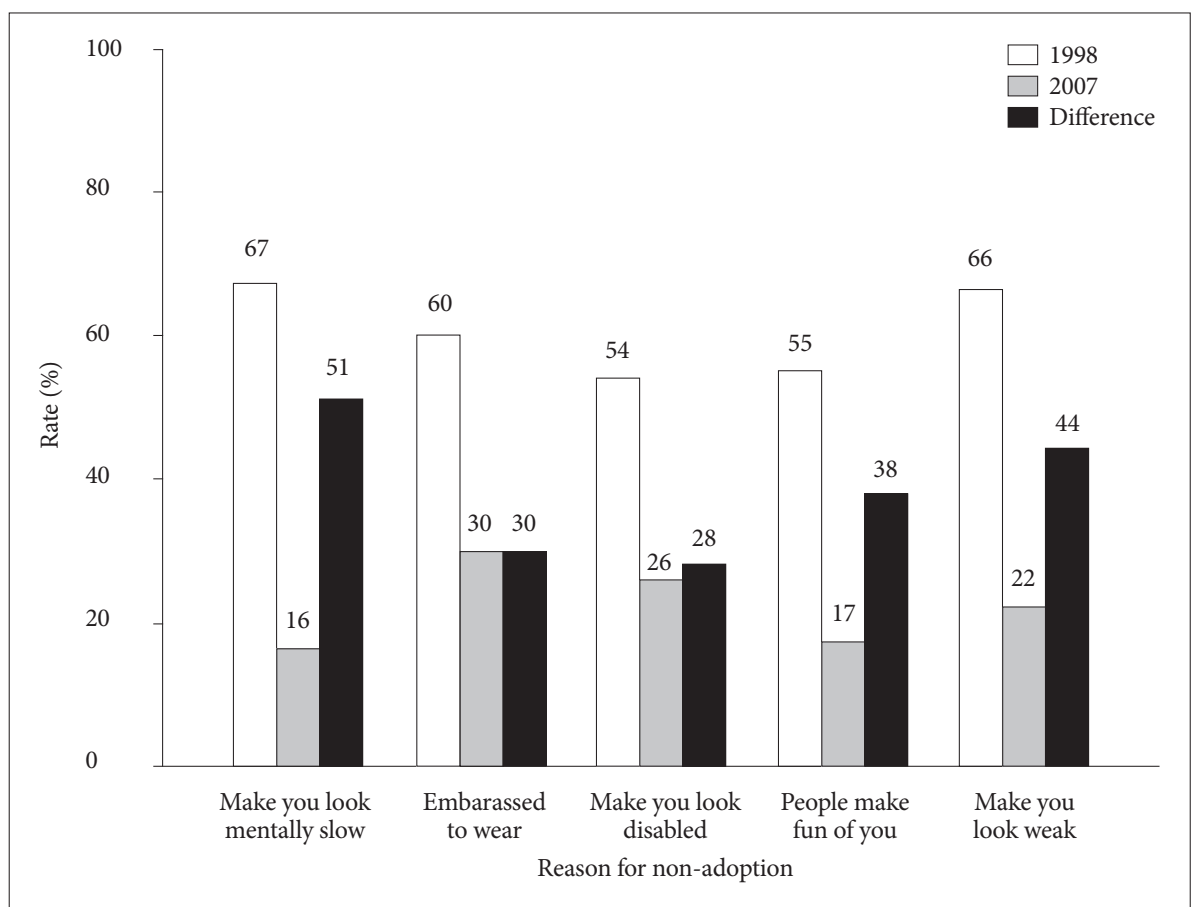


생각되는 비율은 1998년보다 2007년의 보고서에서 감소된 것 으로 나타났다(Figure 7). 1998년에는 '정신적으로 허약해 보임' 이 $67 \%$ 로 가장 높은 비율을 나타냈고, 그 다음으로 '신체적으 로 허약해 보임'이 $66 \%$, ‘착용하기 부끄러움'이 $60 \%$, 사람들이 조롱함'이 55\%, '장애인으로 보임'이 54\% 순으로 나타났으나 2007년에는 '정신적으로 허약해 보임'이 $16 \%$ 로 5 위, 그 이후의 순서는 각각 '사람들이 조롱함'이 $17 \%$, '신체적으로 허약해 보임' 이 $22 \%$, '장애인으로 보임'이 $26 \%$, '착용하기 부끄러움이 $30 \%$ 로 나타났다. 그중 '장애인으로 보임'은 1998년에 가장 낮은 비 율을 보였으나 2007년에는 $26 \%$ 로 나타나 두 기간 동안의 차이 가 $28 \%$ 감소폭으로 가장 적은 것으로 나타났다. 또한 '정신적으 로 허약해 보임' '신체적으로 허약해 보임' '사람들이 조롱함'은 1998 년에 비해 2007년에 51\%, 44\%, 38\%씩 각각 감소한 것으로 나타났다(Kochkin, 1998, 2007). 이는 보청기 착용에 영향을 주는 심리·사회적 요인의 변화가 있는 것으로 해석되고, 그 변 화는 보청기에 대한 부정적 인식이 개선되고 있는 것으로 생각 할 수 있다. 이러한 현상은 미국에서 빌 클린턴이나 조지 부시와 같은 전직 대통령들이나 저명한 인사들이 보청기를 사용하고 있다는 사실이 대중에 알려지면서 보청기 착용에 대한 부정적 인식이 변화되었고 동시에 보청기 착용자를 바라보는 부정적인 시선도 긍정적으로 전환된 것으로 저자는 분석하고 있다 (Kochkin, 2007).

1년 이내 보청기를 구매할 의향에 영향을 주는 요소

보청기를 향후 1 년 이내에 구매한다는 가정하에 구매에 영향 을 주는 요인에 대하여 MarkeTrak 보고서는 2007년과 2012년 에 조사하였다. 두 번의 조사에서 '본인 청력이 더 나빠졌기 때
문이다가 모두 첫 번째 요인으로 나타났다. 이는 1990년 조사 내용 중 보청기를 착용하지 않는 가장 큰 요인으로 '본인의 청력 이 보청기를 할 정도로 나쁘지 않기 때문이다라는 결과와 일맥 상통하고 있다. 이러한 결과를 분석할 때, 난청인은 보청기를 착 용할 의사가 있다면 스스로 청력이 나빠졌다고 인정하는 단계 에서 실질적으로 보청기를 구매하는 것으로 해석할 수 있다. 그 외 보청기를 구매하는 데 영향을 준 요인으로 가족 구성원의 권 유, 안전에 대한 걱정과 청능사(audiologist)의 권유, 이비인후과 에서의 권유 순서로 나타났다(Kochkin, 2007, 2012) (Figure 8). 실제로 보청기를 처음 구매한 경우, 가족의 추천, 청능사 혹은 이비인후과 의사의 권유 등이 그 외 보청기 구매 요인으로 나타 났으나, 홍보매체 광고를 보고 구매를 결정하는 비율은 약 $4 \%$ 로 매우 적어 광고나 홍보가 보청기의 실제 구매에 미치는 영향은 미미한 것으로 나타났다(Kochkin, 1997, 2000, 2005).

\section{전문가에 의한 보청기 적합 및 보급}

보청기를 판매하고 적합을 하는 전문가의 현황에 대한 조사 는 1984년, 1994년, 2004년, 2008년 4번 조사하였는데, 1984년 과 2008년에 변화가 두드러지게 나타났다. 보청기 판매와 적합 을 한 전문가가 보청기 판매업자(hearing specialist)인 경우는 $66 \%$ 에서 $31 \%$ 로 하락한 반면, 청능사인 경우는 $22 \%$ 에서 $63 \%$ 로 상승하였다. 더욱이 보청기 판매와 적합을 하는 전문가가 청 능사인 경우는 1994년, 2004년, 2008년에 49\%, 55\%, 63\%로 꾸 준히 증가되는 추세로 분석되었다(Kochkin, 1996, 2005, 2009) (Figure 9).

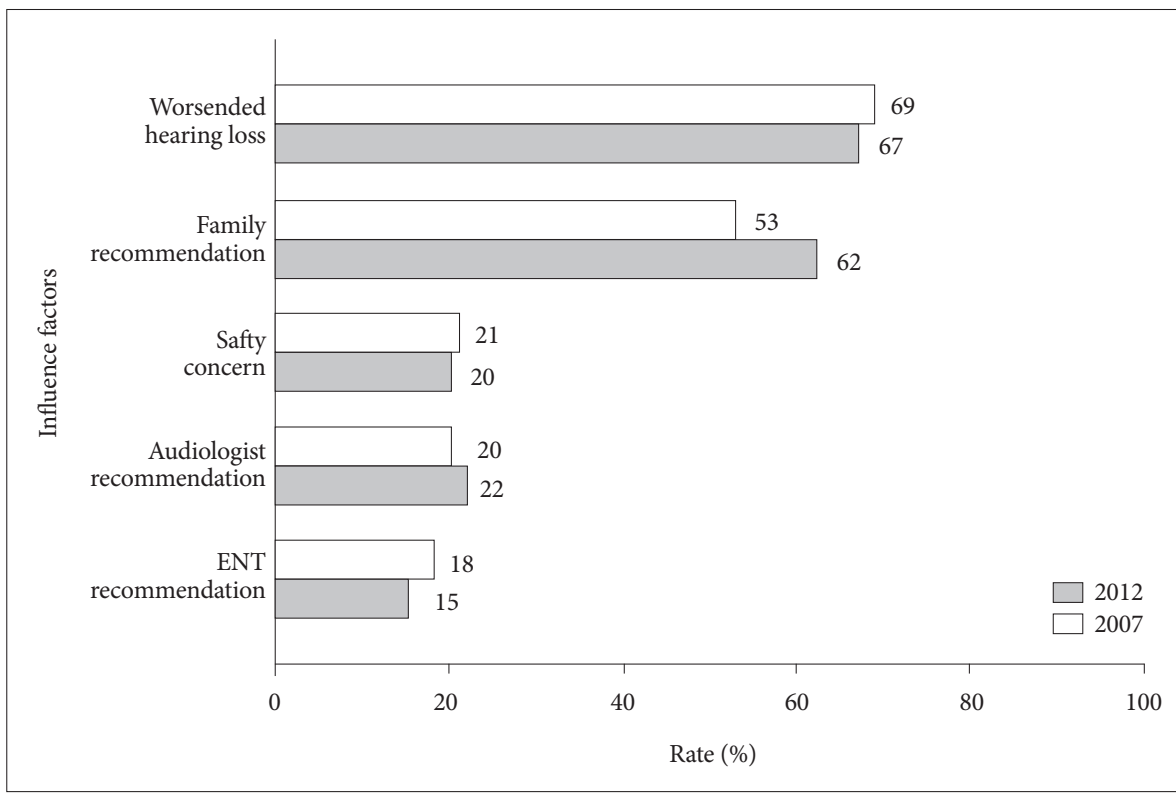

Figure 8. Influent factors before and after purchasing hearing aids. ENT: ear, nose, and throat. 
Figure 9. Dispensing of hearing aid fitting by profession.

\section{경제적 요소(Financial factors)}

\section{보청기의 평균 구매 가격}

1984년 조사 초기의 보청기 평균 가격은 US\$ 501이고, 2015 년 보청기 평균 가격은 US\$2,347로 31년간 가격이 $368 \%$ 상승 된 것으로 나타났다. 특히 1990년대 중반에 디지털 보청기가 개발된 이후로 보청기 가격이 US\$1,000을 넘기 시작해 2015 년 개당 평균 판매 가격은 US\$2,000을 넘은 것으로 나타났다. 그러나 최근 미국 내에서 기존 보청기 유통 경로가 아닌 코스 트코와 같은 대형 할인마트나 온라인을 통해 음성증폭기 형태 로 판매되는 경우가 있어 보청기 판매 평균 가격이 다소 하락 하는 경향이 나타나고 있다. 또한 보청기 수요의 증가를 해소하 기 위해 2017년에 경중도 성인 난청자에 한해서는 청각 전문가 의 도움 없이 일반 상점 카운터(over-the-counter, OTC)에서 보청기를 판매할 수 있도록 하는 법안이 통과되어 앞으로 보청 기 유통 체계와 가격에 변화가 예상되고 있다(Hearing review, 2017). 그러나 이러한 정책적 변화는 경중도 난청자도 보청기를 쉽게 구매하고자 하는 요구가 받아들여진 것으로, 인구의 고령 화에 따라 증가하는 보청기 수요에 대처하기 위한 하나의 정책 적 방편으로 생각할 수 있다. 우선 증가하는 보청기 수요의 요 구를 해소하기 위해 법안은 통과시켰으나 성인 경중도 난청자 가 청각전문가의 지도 없이 OTC에서 구매할 수 있는 보청기의 성능 및 기준이 아직 마련되지 않아 미국 FDA에서 앞으로 3년 간 세부 규정을 더 정리한 이후 시행할 예정이어서 어떤 형태로 OTC 판매가 이루어질지는 미지수이다. 이는 보청기는 단순한 음성증폭기와 달리 구매의 결정, 사용, 사후 평가까지도 청각전 문가가 개입되어야 하는 복잡한 의료기기임을 뜻한다고 해석할
수 있고, 미국 내 관련 단체들이 다양한 경로로 전문가의 필요 성을 알리고 있다. 보청기 가격과 관련하여 보청기가 가장 필요 한 중고도 난청자에게 2년 안에 보청기와 관련해 필요한 재정 적 지원을 원하는 방향에 대하여 조사하였을 때, 건강보험에서 $100 \%$ 비용을 부담해 주기를 바라는 경우가 $66 \%$ 로 가장 높게 나타났고, 그 다음 비율로 보청기의 가격이 1984년대와 같이 US\$ 500 이하로 낮아져야 한다는 경우, US\$1,000 이상의 보험 료 지원을 바라는 경우, 수리 비용 인하를 바라는 경우가 각각 $47.4 \%, 47.3 \%, 47.1 \%$ 로 유사하게 나타났다(Kochkin, 2012).

\section{DISCUSSIONS}

본 연구에서 분석한 MarkeTrak 보고서에 의하면 1984년에 서 2014년까지 30년간 미국의 보청기 착용률은 24\%에서 30\% 로 $6 \%$ 증가한 반면, 보청기 판매 대수는 약 120 만 대에서 320 만 대로 $167 \%$ 가 증가한 것으로 보고하고 있다. 이러한 비약적 인 판매 대수의 양적 증가 원인은 전체 인구수의 증가, 난청 출 현율의 증가, 양이 착용률의 증가 등으로 해석할 수 있다. 특히 양이 착용률은 1984년에는 53\%에 불과했으나 2008년에는 $78 \%$ 로 보청기 구매자의 10 명 중 8 명이 양이 착용을 하는 것으 로 나타났다(Abrams \& Kihm, 2015). 이러한 높은 양이 착용 률은 보청기 판매 대수의 증가는 물론 전반적인 보청기에 대한 만족도 상승에도 영향을 미친 것으로 분석되었다. 그 이유는 미국의 전반적인 보청기 보급률은 $30 \%$ 정도로 영국, 독일, 프 랑스의 평균인 $37 \%$ 정도에 비해 상대적으로 낮지만, 양이 착용 률은 유럽 3개국의 $69 \%$ 보다 $78 \%$ 로 약 $10 \%$ 더 높을 뿐 아니 라, 전반적인 보청기 만족도도 유럽의 $62 \%$ 에 비해 더 높은 $81 \%$ 
로 약 20\%가 더 높은 것으로 보고되었기 때문이다(Bisgaard \& Ruf, 2017; Kochkin, 2012). 따라서 보청기의 양이 착용률은 보청기 만족도와 관련이 있는 것으로 해석할 수 있다. Ahn(2010) 에 의한 연구에 따르면 국내의 보청기 양이 착용 비율은 불과 $20 \%$ 여서 미국이나 유럽의 보청기 양이 착용률에 비해 매우 낮 은 것으로 나타났다. 이는 국내의 보청기 만족도의 저하를 초 래하고 지속적인 보청기 착용의 동기부여 등에도 부정적인 영 향을 미칠 수 있는 점이 우려되고 있으며 이러한 현상은 국내 보청기 시장에 반영될 가능성이 있는 것으로 생각된다.

청취 환경에 따른 어려움에 관한 조사에서 MarkeTrak 보고 서에서 나타난 바와 같이 국내 착용자도 직장이나 학교와 같은 장소가 어려운 청취 환경으로 보고되었다(Chang et al., 2014). 이러한 청취 환경에 따른 보청기 만족도의 저하는 보청기 착용 자의 $95 \%$ 가 소음 속에서 말소리 청취의 기능이 지금보다 더 개 선되어야 한다는 조사결과와 일치하는 결과를 나타내고 있다. 1990년대 후반부터 프로그래머블(programmable) 보청기와 디 지털 보청기의 발달로, 소음 감소 기술, 알고리즘의 개선, 방향 성 마이크로폰 기술이 보청기에 적용되어 이전보다는 소음 속 청취 기술이 많이 개선되었음에도 불구하고 여전히 소음 속 청 취 환경의 만족도가 낮은 것으로 나타나 앞으로 보청기 개발에 중요한 요소이고 확실히 개선되어야 할 부분으로 생각된다.

귀걸이형 보청기 중 RIC형으로 출시된 오픈형 보청기와 일 반적 귀걸이형 보청기의 만족도를 비교한 자료에서 RIC형 보청 기는 일반적 귀걸이형 보청기에 비해 더 만족도가 높은 것으로 나타났다. 구체적으로 RIC형 보청기는 볼륨 조절의 용이성 항 목을 제외한 모든 항목인 착용의 편안함, 배터리 수명, 소음 속 청취, 외관, 음식물 섭취 시 불편함 등의 항목에서 더 높은 만 족도를 나타내고 있다(Kochkin, 2011). 이러한 현상은 보청기 형태별 구매 비율에도 변화를 주고 있는데, 예를 들어 RIC형 보청기 구매 비율이 $69 \%$ 로 귓속형의 $17 \%$ 나 일반적 귀걸이형 의 $14 \%$ 에 비해서 높은 비율인 것으로 나타났다(Strom, 2017). 그러나 국내 보청기의 형태별 구매 비율은 일반 귓속형 보청기 가 $40.9 \%$ 로 제일 많았고, 그 다음은 고막형 보청기 $28.5 \%$, 귀걸 이형 보청기 $24.2 \%$, 외이도형 보청기 $6.5 \%$ 순으로 보고되었다 (Ahn, 2010). 또한 국내 네 개의 보청기 제조회사 생산 및 출고 현 황에서도 일반 귓속형 보청기의 출고 현황이 $37.2 \%$ 로 가장 많았 고, 그 다음으로 고막형이 $24.8 \%$, 외이도형이 $5.2 \%$ 로 조사되어 유사한 비율로 보고하였다(Lee, 2010). 이를 종합할 때 국내 보 청기의 형태별 구매 비율은 MarkeTrak 보고서와 달리 아직 귓 속형 보청기가 우세한 것을 확인할 수 있다. 아마도 우리나라의 귓속형 보청기의 높은 선호도는 외관상 눈에 띄는 것에 대한 거 부감을 상대적으로 더 크게 느끼는 보청기 착용자가 더 많은 것 으로 추정할 수 있다.
Surr et al.(2001)은 최신 기술을 탑재한 보청기라 하더라도 모든 청취 환경에서 $100 \%$ 완벽하게 착용자가 원활하게 청취하 도록 할 수는 없으므로 음량조절장치를 필수적으로 제공할 것 을 제안하고 있다. MarkeTrak 보고서에서도 기존 보청기 착용 자군에서 음량조절기의 탑재를 선호하였으나 현실적으로 음량 조절기의 탑재 비율은 1994년 98\%에서 2001년에 75\%로 감소 된 점을 고려할 때 보청기에서 음량조절기의 활용을 다시 고려 해 볼 필요가 있다. 더욱이 최근 보청기 기술의 발전으로 음량 조절기는 보청기의 무선 통신 기술과 접목을 통해 조절이 가능 하고 휴대전화, 태블릿 $\mathrm{PC}$, 오디오, TV, MP3 등과 같은 다양 한 청취기기들과 무선으로 연결하여 청취를 원활하게 할 수 있 는 기능도 보청기에 탑재될 수 있도록 개발되어 있다. 예를 들 어 음량조절장치를 보청기에 탑재하지 않고 별도의 무선 리모 컨 형태의 액세서리를 이용하거나 스마트폰의 어플리케이션을 통해 음량을 조절하고 프로그램이나 각종 세팅을 변경할 수 있 는 기능 등이 현재 활용되는 대표적 방식이다. 또한 추가적인 음량조절장치를 탑재하여 외관적으로 보청기의 크기가 커지거 나 조작이 불편한 단점들을 극복할 수 있는 새로운 기술이 개 발되고 있어 청능사는 난청자에게 적합한 보청기를 권유하거나 선택을 상담을 할 때 이러한 기술에 대한 소개를 하고 사용방 법에 대한 구체적인 설명을 하는 것이 중요할 것으로 생각된다.

난청이 있음에도 불구하고 가장 보편적으로 난청을 극복할 수 있는 보조기인 보청기를 사용하지 않는 가장 큰 요인은 심 리·사회적 요인 때문이라고 할 수 있다. MarkeTrak 보고서에 서 나타났듯이 주요 착용의 동기는 청력 악화를 스스로 느겼을 경우인데 그 외의 보청기 착용의 동기를 높여주는 요인에는 청 능사나 이비인후과 의사와 같은 청각전문가의 권유도 영향력이 있는 것으로 나타났다. 더욱이 MarkeTrak 보고서 9권에 따르 면 보청기 착용자의 $93 \%$ 와 보청기 비착용자의 $83 \%$ 가 청능사 의 역할에 대해 신뢰도와 만족도를 나타내는 것으로 나타났다 (Abrams \& Kihm, 2015). 또한 보청기 구매를 결정하는 동기 에 대한 분석에서도 가장 중요한 요소가 보청기를 권유하는 전 문가의 전문성 여부로 나타나서 보청기의 적합, 조절, 유통 단 계에서 청능사의 관련 지식에 대한 전문성이 중요한 것으로 나 타났다(Kochkin, 2002a). 따라서 청능사는 난청자들에게 양질 의 서비스와 전문성을 제공할 수 있도록 역량을 스스로 강화 하고 관련 기관에서 제공하는 재교육이나 세미나 등에 새로운 기술을 습득하여 전문성을 증가시켜 보청기 만족도를 상승시 킬 수 있도록 노력하는 자세가 필요할 것으로 생각된다.

미국 내 보청기 평균 판매 가격은 US\$2,000 이상으로 보고 되었고 양이 착용자가 대다수임을 고려하면 실질적 보청기 구 매 비용은 약 US $\$ 4,000 ~ 5,000$ 인 것으로 생각할 수 있다. 그러 나 이러한 구매 비용은 보청기 구매 시 이용할 수 있는 할부 활 
용과 금융 지원 시스템이 매우 잘 되어 있고 다양한 보험 및 보 상 체계가 있어 실질적으로 구매자에게 큰 부담이 되지는 않는 것으로 알려져 있다. 국내의 경우, 실질적인 판매 금액에 대한 정 확한 자료를 찾기 어렵지만 150 만 원에서 200만 원 미만 제품대 의 구매 비중이 $25.9 \%$ 라는 조사연구(Ahn, 2010)와 실구매 가격 이 아닌 소비자 가격표 기준으로 200만 400만 원대의 보청기가 가장 많이 보급되는 것으로 조사된 자료(Lee, 2010)로 유추하 면 국내 보청기 평균 구매 가격은 200만 원 내외이고 이 가격대 의 보청기가 선호되고 보급되는 것으로 추정할 수 있다. 국내의 보청기 구매에 관한 지원정책은 2014 2018년 건강보험 중기 보 장성 강화 계획의 일환으로 보청기 구매 지원금이 차상위 계층 이상에 대해 최대 34만 원에서 131만 원으로 2015년에 상향 조 정되었다. 그러나 정책의 결정과 시행에 있어서 체계적인 조사 를 기반으로 지원금이 산정되었는지에 대해서 청각장애인, 청 능사, 보청기 제조 및 공급자 간에 이견이 존재하는 것으로 보 고 되었다(Chang et al., 2017). 따라서 체계적인 조사를 바탕으 로 현실적이고 합리적인 보청기 지원금 정책 수립이 절실한 것 으로 파악되었다.

세계적으로 대표적인 보청기 만족도 및 시장 동향에 대한 조 사는 미국의 MarkeTrak 보고서와 유럽의 EuroTrak 보고서인 데 두 보고서 모두 10년 이상 오랜 기간 광범위하게 보청기 시장 동향에 대한 조사를 바탕으로 보청기 만족도의 구체적 요인과 변화 등을 지속적으로 분석한 체계적인 보고서를 제시하고 있 다. 또한 미국과 유럽에 보청기 만족도의 긍정적이고 부정적인 요인을 세분화하여 분석하고 기술에 적용하여 보청기 착용에 대한 만족도를 극대화할 수 있는 새로운 보청기 기술 개발의 지 표를 제공하고, 궁극적으로 난청자의 보청기 착용 범위를 확대 하는 데 중요한 역할을 하고 있다. 그러나 국내의 보청기 시장 에 대한 조사는 2015년 7월 한국보건산업 진흥원에서 발간한 보청기 국내외 시장 분석이나 단편적인 연구가 전부이다. 더욱 이 이미 발간된 문헌을 고찰하거나 국내 보청기 시장 전체를 다 루기보다는 특정 병원, 보청기 센터, 개인에 대한 만족도 조사 에 국한되어 있어, 보편적 보청기 시장의 동향과 보청기 만족도 를 분석한 자료를 대표하기에는 어려움이 있다. 최근 2010년 한 국보건의료연구원에서 전국 12 개 종합병원의 내원환자 300 여 명을 대상으로 한 설문조사가 있으나(Ahn, 2010) 국내 보청기 시장의 $80 \%$ 이상이 병원 외의 전문 보청기 센터나 보청기 판매 상에서 형성되는 점을 감안하면 다소 좁은 범위의 조사라 할 수 있다. 따라서 최근 국내 시장의 동향을 반영한 보편적이고 포괄적인 보청기 시장 현황과 보청기 착용자의 만족도에 대한 조사의 필요성이 대두되고 있다. 보청기 사용자의 실태에 대한 체계적이고 광범위한 조사는 우리나라 난청의 정확한 현황과 청각장애인 및 보청기 착용자들의 요구를 충분히 반영할 수 있
어 보청기의 만족도를 상승시킬 수 있고 그에 따른 보청기 시장 의 확대에 기여할 수 있다. 따라서 본 연구는 MarkeTrak 보고 서나 EuroTrak 보고서와 같은 국내 정서를 반영한 체계적인 보고서의 필요성을 제시하였다. 본 고의 분석 내용들을 반영하 면 국내의 이러한 보고서 제작에 도움이 될 수 있을 것으로 생 각하며 가제 KoreaTrak의 출현을 기대한다.

중심단어 : 보청기·보청기 만족도·보청기 시장 동향·MarkeTrak.

\section{Ethical Statement}

N/A

Acknowledgments

N/A

Declaration of Conflicting Interests

There are no conflict interests.

Funding

N/A

\section{REFERENCES}

Abrams, H. B. \& Kihm, J. (2015). An Introduction to MarkeTrak IX: A New Baseline for the Hearing Aid Market. The Hearing Review. Retrieved from http://www.hearingreview.com/2015/05/introduction-marketrak-ix-new-baseline-hearing-aid-market/.

Ahn, J. H. (2010, December 31). Analysis of Obstacle and Benefit of Hearing Aid Usage of Hearing Impaired Patient. National Evidence-Based Healthcare Collaborating Agency. Retrieved from pomacis.nl.go.kr/upload/ nl/311767/ 20170410/UMO20150165179.pdf.

Anovum. (2013). EuroTrak2012: 100,000 people surveyed. Audio infos, 76, $12-13$.

Bisgaard, N. \& Ruf, S. (2017). Findings from EuroTrak surveys from 2009 to 2015: Hearing loss prevalence, hearing aid adoption, and benefits of hearing aid use. American Journal of Audiology, 26(3S), 451-461.

Chang, Y. S., Choi, J., Park, G. Y., Youm, H. Y., Byun, H. Y., \& Cho, Y. S. (2014). Evaluation of satisfaction with hearing aids using a questionnaire based on MarkeTrak survey. Korean Journal of Otorhinolaryngology-Head and Neck Surgery, 57(5), 304-313.

Chang, J. H., Hong, C. E., Park, J. C., Choi, J. K., \& Choi, H. S. (2017). Determinants analysis of satisfaction with supporting system for hearing aids. Korean Journal of Otorhinolaryngology-Head and Neck Surgery, 60(8), 381-389.

EHIMA. (2016, May). Hearing Aids Improve Hearing, - and a LOT More: Trends Derived from the EuroTrak Databases 2009-2015. Ehima. Retrieved from https://www.ehima.com/wp-content/uploads/2016/05/eurotrak-trends-2009-2015-and-mt9_.pdf.

Kang, Y. S., Lee, J. J., Lee, Y. R., Mun, H. A., Choo, O. S., Kim, T., et al. (2016). Development of simplified Ajou version of MarkeTrak survey to evaluate hearing aid use. Korean Journal of Otorhinolaryngology-Head and Neck Surgery, 59(10), 706-724.

Kim, S. H., Lee, Y. H., Hwang, J. H., Oh, M. A., Lee, M. K., Lee, N. H., et al. (2014). Survey of the living conditions of disabled people. Sejong: Korea Institute Health and Social Affairs.

Kochkin, S. (1990). Introducing MarkeTrak: The consumer tracking survey of the hearing instruments market. The Hearing Journal, 43(5), 1-8.

Kochkin, S. (1996). MarkeTrak IV: 10 year trends in the hearing aid market: Has anything changed? The Hearing Journal, 49(1), 23-34.

Kochkin, S. (1997). MarkeTrak IV: What is the viable market for hearing aids? The Hearing Journal, 50(1), 31-38. 
Kochkin, S. (1998). MarkeTrak IV: Correlates of hearing aid purchase intent. The Hearing Journal, 51(1), 30-38.

Kochkin, S. (2000). MarkeTrak V: Customer satisfaction revisited. The Hearing Journal, 53(1), 1-8.

Kochkin, S. (2002a). MarkeTrak VI: Consumers rate improvements sought in hearing instruments. The Hearing Review, 9(11), 18-22.

Kochkin, S. (2002b). MarkeTrak VI: Factors impacting consumer choice of dispenser \& hearing aid; Use of ALDs \& computers. The Hearing Review, 9(12), 14, 18, 20, 22, 23.

Kochkin, S. (2003). MarkeTrak VI: Isolating the impact of the volume control on customer satisfaction. The Hearing Review, 10(1), 26-35.

Kochkin, S. (2005). MarkeTrak VII: Customer satisfaction with hearing instruments in the digital age. The Hearing Journal, 58(9), 30-39.

Kochkin, S. (2007). MarkeTrak VII: Obstacles to adult non-user adoption of hearing aids. The Hearing Journal, 60(4), 24, 26, 28, 31-34, 36-41, 44, $46,48,50$.

Kochkin, S. (2009). MarkeTrak VIII: 25 year trends in the hearing health market. The Hearing Review, 16(11), 12, 14, 16, 18-20, 22-24, 26, 28, 30, 31.

Kochkin, S. (2010). MarkeTrak VIII: Consumer satisfaction with hearing aids is slowly increasing. The Hearing Journal, 63(1), 19-27.

Kochkin, S. (2011). MarkeTrak VIII: Mini-BTEs tap new market, users more satisfied. The Hearing Journal, 64(3), 17, 18, 20, 22, 24.

Kochkin S. (2012). MarkeTrak VIII: The key influencing factors in hearing aid purchase intent. The Hearing Review, 19(3), 12-25.

Lee, S. Y. (2010). Proceedings from 13th Korean academy of audiology conference: Selling Report of Korean Hearing Aid in 2009. Gwangju, Jeonnam: Nambu university.
Lemke, U. \& Scherpiet, S. (2013). Oral communication in individuals with hearing impairment-considerations regarding attentional, cognitive and social resources. Frontiers in Psychology, 6, 998.

Lin, F. R., Yaffe, K., Xia, J., Xue, Q. L., Harris, T. B., Purchase-Helzner, E., et al.; the Health ABC Study Group. (2013). Hearing loss and cognitive decline in older adults. JAMA Internal Medicine, 173(4), 293-299.

Ministry of Health and Welfare. (2016, July). The Number of Registered Disabled Person. KOSIS. Retrieved from http://kosis.kr/statHtml/statHtml. do?orgId=117\&tblId=DT_11761_N001\&vw_cd=MT_OTITLE\& list_ id $=101 \_11761 \&$ seqNo $=\& l a n g \_$mode $=$ko\&language $=$kor\&obj_var id=\&itm_id=\&conn_path=K2.

Mueller, G. (2012 July). 20Q: More Highlights from MarkeTrak. AudiologyOnline. Retrieved from http://www.audiologyonline.com/articles/ more-highlights-from-marketrak-6830.

Saito, H., Nishiwaki, Y., Michikawa, T., Kikuchi, Y., Mizutari, K., Takebayashi, T., et al. (2010). Hearing handicap predicts the development of depressive symptoms after 3 years in older community-dwelling Japanese. Journal of the American Geriatrics Society, 58(1), 93-97.

Strom, K. E. (2017). Staff standpoint: Hearing aid sales in Q3 2017 on low side of normal. The Hearing Review, 24(11), 6.

Surr, R. K., Cord, M. T., \& Walden, B. E. (2001). Response of hearing aid wearers to the absence of a user-operated volume control. The Hearing Journal, 54(4), 32-36.

U.S. Food and Drug Administration. (2017, April). CFR-Code of Federal Regulation Title 21. U.S. Food and Drug Administration. Retrieved from https://www.fda.gov/MedicalDevices/DeviceRegulationandGuidance/ HowtoMarketYourDevice/PremarketSubmissions/PremarketApprovalPMA/ucm050390.htm. 